\title{
Strong Room: Material Memories and the Digital Record
}

\author{
Roelof Bakker \\ Cambridge School of Art, Anglia Ruskin University, Cambridge, UK \\ Jane Wildgoose \\ Centre for Life-Writing Research, King's College London, UK
}

\section{ABSTRACT}

Strong Room, by the artist and researcher Jane Wildgoose and the artist Roelof Bakker, was published in 2014 by Negative Press London, a small press established by Bakker with the aim of initiating collaborations in print between artists and writers. Strong Room mixes photographs showing traces of preserved past human activity with writing, which highlights the loss of tangible experience and lack of physical presence in the digital world. Reflecting on the aesthetics of abandoned workspaces and the historical and academic importance of paper-based archives, Bakker and Wildgoose explore the potential for perceptions of materiality to prompt the imagination and evoke memories. In this article, the artists reflect on a range of subjective responses to archives and archival materials and discuss the background to their collaborative approach to developing the book: presenting a selection of Bakker's photographs together with extracts from the accompanying essays in Strong Room.

Keywords: memory, materiality, archives, remains 


\section{STRONG ROOM}

ROELOF BAKKER \& JANE WILDGOOSE

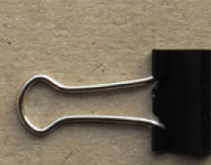

Strong Room was produced by the artist and publisher Roelof Bakker in collaboration with the artist and researcher Jane Wildgoose and published by Bakker's Negative Press in 2014. Strong Room brings together Bakker's photographs showing traces of preserved past human activity in abandoned municipal workspaces with Wildgoose's writing, in which she reflects on the experience of accessing nineteenth-century correspondence in the archives of a medical museum. Focusing closely on the material qualities of archival spaces and documents, and the physical and emotional resonance of their encounters with them, the artists highlight inter-relationships between sensory perceptions and memory: drawing attention to the loss of tangible experience and lack of physical presence in the digital world, at a time when digitisation increasingly impacts on the maintenance of and access to archival material. 


\section{VOICES FROM THE ARCHIVE}

As Rebecca Duclos reflects in her study of the "information-seeking behaviours" of contemporary artists, The Compulsive Browse, the 'desire to examine, extract, and enfold "real world" information into artistic practice,' though 'not necessarily new,' is nonetheless 'a phenomenon' she has seen 'intensify significantly in recent years'. ${ }^{1}$ Discussing a series of in-depth interviews she conducted with Canadian artists, in which she encouraged them 'to articulate how they "describe and legitimate inference, intuition, synchronicity, chance and insight", as forces that reframe, redirect or enhance their projects', Duclos observes that "in textual explications, the dynamic of these iterative moments is often smoothed over."'2 Such moments of intuition and insight and the bearing they may have on the artist as witness, are of special interest to Bakker and Wildgoose: informing their practice as artists and the related texts they produce. Like many of the artists interviewed by Duclos, Bakker and Wildgoose are keen 'to recuperate micro-histories, investigate obscure archives and locate esoteric ephemera', employing 'research processes' that are at once 'intuitive, associative, synchronous, non-linear and highly subjective'. ${ }^{3}$

The impulse to communicate a deeply subjective response to archival materials has been eloquently advanced elsewhere by the American poet Susan Howe, whose body of work over four decades is characterised by her close engagement with historical texts and archival documents. Discussing the evolving 'electronic technologies' that have rapidly advanced in recent years, which 'provide myriad possibilities for artists, poets, academics, auto-didacts, and librarians, in terms of storage, access and research', Howe registers concern that those same technologies are also 'radically transforming the way we read, write and remember'. Citing Henry James's recollection of visiting the Law Library at Harvard University at the beginning of the twentieth century, where he found himself "sniffling the very dust, prehistoric but still pungent, of the old," the poet offers an impassioned hymn of praise to the 'old ways': the interconnected sensory reactions that may occur when archival materials are accessed in "real world" rather than digital forms. Describing "the inward ardor' that she experiences 'when working in research libraries', Howe defines her response to archival materials as being 'intuitive': a kind of 'mystic, documentary telepathy'.

The photographer Dayanita Singh-whose analogue black and white images of working archives in India evoke the barely contained, though nonetheless ordered chaos of paper-based archives variously threatened by monsoon floods, sweltering humidity and infestations by insects and rodents-feels that it is as if 'the work has really been possessed by some 
other force'. Describing the sensation of entering the repositories that have captured her imagination for over a decade-in government offices; at the tram depot in Calcutta; in private homes, and including 'the Maharana of Udaipur's archive, going back to the fourteenth century where everything that the Maharana did, every day, is recorded'-the artist recalls that 'the excitement for me when I walked into... [such a] room was almost like a sexual excitement, or beyond sexual excitement. Just to see that room full of secrets, where one fact and one file could make such a difference to one person's life but they are just lying there dormant until the right person comes in'. Singh is clear that it is not solely the information contained in these rooms that consumes her interest. When invited to return at a later date to photograph some of the archives because their custodians would by then have finished the process of digitising the materials they contained, her answer was an emphatic 'No, no, no, I want [to photograph] it before that'. ${ }^{5}$ [Emphasis in original.]

The historian and political scientist Achille Mbembe also attests to 'the material nature of the archive—at least before digitization- [which] means that it is inscribed in the universe of the senses: a tactile universe because the document can be touched, a visual universe because it can be seen, a cognitive universe because it can be read and decoded' ${ }^{6}$ Contributing to a series of seminars that took place in Johannesburg in 1998, accompanied by an exhibition 'of work by contemporary South African artists who explore the activities of documentation as processes of interpretation', ${ }^{7}$ Mbembe proposes that, with its 'labyrinth of corridors, and that degree of discipline, half-light and austerity', the architectural space of the archive assumes an authority that has 'something of the nature of a temple and a cemetery: a religious space because a set of rituals is constantly taking place there... of a quasi-mystical nature, and a cemetery in the sense that fragments of lives and pieces of time are interred there, their shadows and footprints inscribed on paper and preserved like so many relics'. ${ }^{8}$ But definitions of the archive as 'a sepulchre', in the context of 1990s South Africa-'when the workings of the Truth and Reconciliation Commission' directly 'confronted...questions of who owns information, representation and memory' ${ }^{9}$ — point not so much to elegiac nostalgia, but rather to tensions between 'archiving' as 'a kind of interment' or 'laying...to rest' (that is, a politically expedient 'burial') and the potential 'violence and cruelty' of which '[archival] remains' (in the form of physical evidences of past injustices) 'are capable', for those whose aim it is to address 'the debt' of the past. ${ }^{10}$

The potential 'violence and cruelty' of the colonial record is only too familiar to the Australian historian Lynette Russell, who has for many years 'accompanied Aboriginal elders to archives... [and] public record 
offices' in order to help them in the process of reclaiming documentary traces of their ancestors' lives. Russell has 'at times needed to proceed with great caution, warning people that there could be extremely unpleasant information that they may choose not to see'. She has 'often seen firsthand the sort of trauma these records can produce'. She has also undertaken research into the medical records of her own Aboriginal great-grandmother who was 'committed to a mental asylum at some time in the 1920s or 30s. ${ }^{11}$ The process of what Mbembe vividly describes as 'the resuscitation of life...bringing the dead back to life by reintegrating them in the cycle of time' ${ }^{12}$ through recourse to the institutional record, has, for Russell, 'presented very particular problems and created a very specific and often times conflicted relationship between me and the archival materials'. She adds that, 'despite my professional training as an historian, I was deeply affected by this material. As the great-granddaughter of the subject of these records, I was often visibly and palpably distressed ${ }^{13}$

While these commentators are active across a wide range of fields and time zones, the American poet, the Indian artist and the South African and Australian historians are united in their articulation (as opposed to suppression) of the profound emotional effects the archive may have on the researcher, as $\mathrm{s} /$ he navigates its labyrinths in search of fragments and traces of life writing. For Russell, digital technologies offer practical opportunities to address 'issues relating to access to, and control of, information about...[Indigenous peoples'] cultures and communities': through the provision of 'archival systems to which Indigenous people and Indigenous knowledge can be interactively added' in ways that are respectful of-and of benefit to-those communities. ${ }^{14}$ For Howe, Singh and Mbembe, the combined effects on the senses of the material qualities of archival materials and spaces, and related rituals of storage and access, are significant factors in the ways in which they go about reading, writing and examining the 'debt' of the past. It was with a keen awareness of the agency of those 'old ways', in a rapidly changing world, that Bakker and Wildgoose embarked on their collaboration to produce Strong Room.

\section{STRONG ROOM: BACKGROUND}

RB: When we met some years ago, Jane and I discovered a shared interest in memory and remembrance, and in traces of past lives that may be found in objects and spaces. I subsequently invited Jane to collaborate on Strong Room, a book project using photographs I had taken at Hornsey Town Hall, a grade II listed building in north London where we had both previously hosted exhibitions. ${ }^{15}$ To reflect our concern with tactile 
qualities and materiality the book is designed with three different paper stocks: firm archival-style Kraft board for the cover, a gentle to touch off-white paper stock for the text and smooth white matt silk stock for optimised reproduction of the photographs; a bulldog clip relates to the book's archival content.

At the time of recording in 2010, the Town Hall had not been in public use for decades. The photographs show well-preserved traces of past human activity and presence in three different areas of municipal life (the Council Chamber, Strong Room and Maintenance Room): fragments of a kind of life writing, which may be detected on objects and spaces.

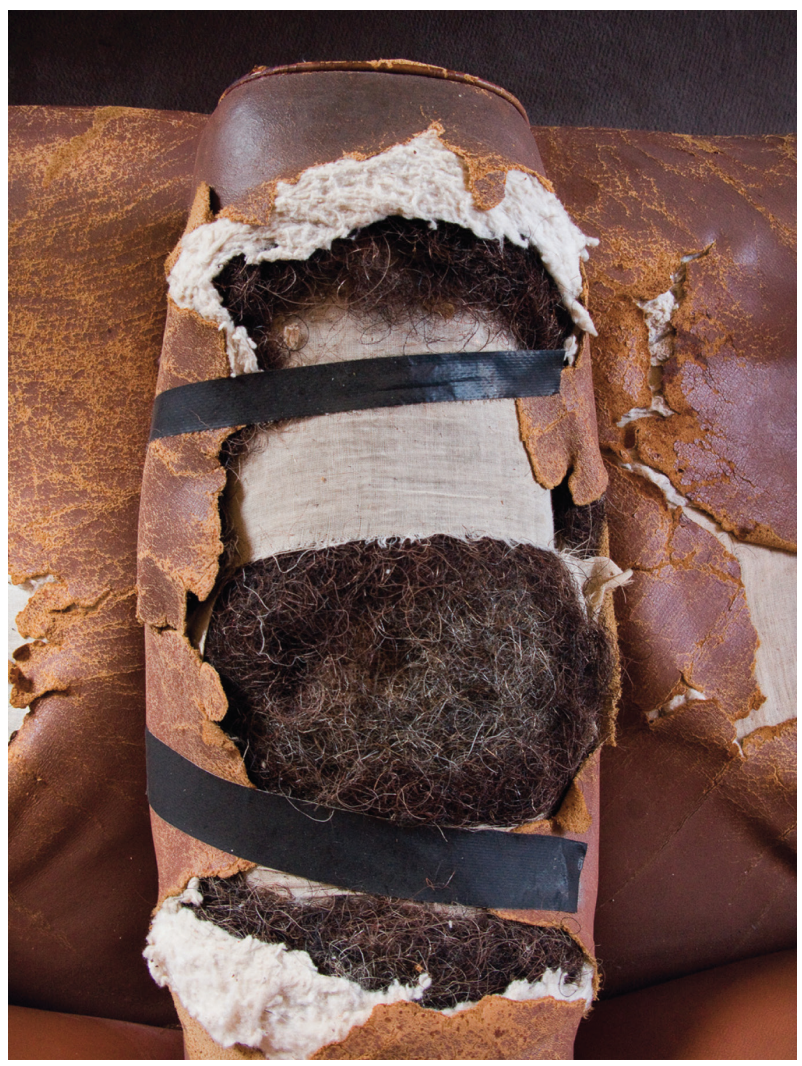

In the Council Chamber, the arms of leather chairs are worn and damaged by the friction of arm movement, exposing different layers of upholstery: leather, horsehair, linen and cotton filling. I observed the chairs furthest away from the mayor experienced the most wear and tear. The damaged 
arms have been temporarily repaired and are held together by heavy-duty tape.

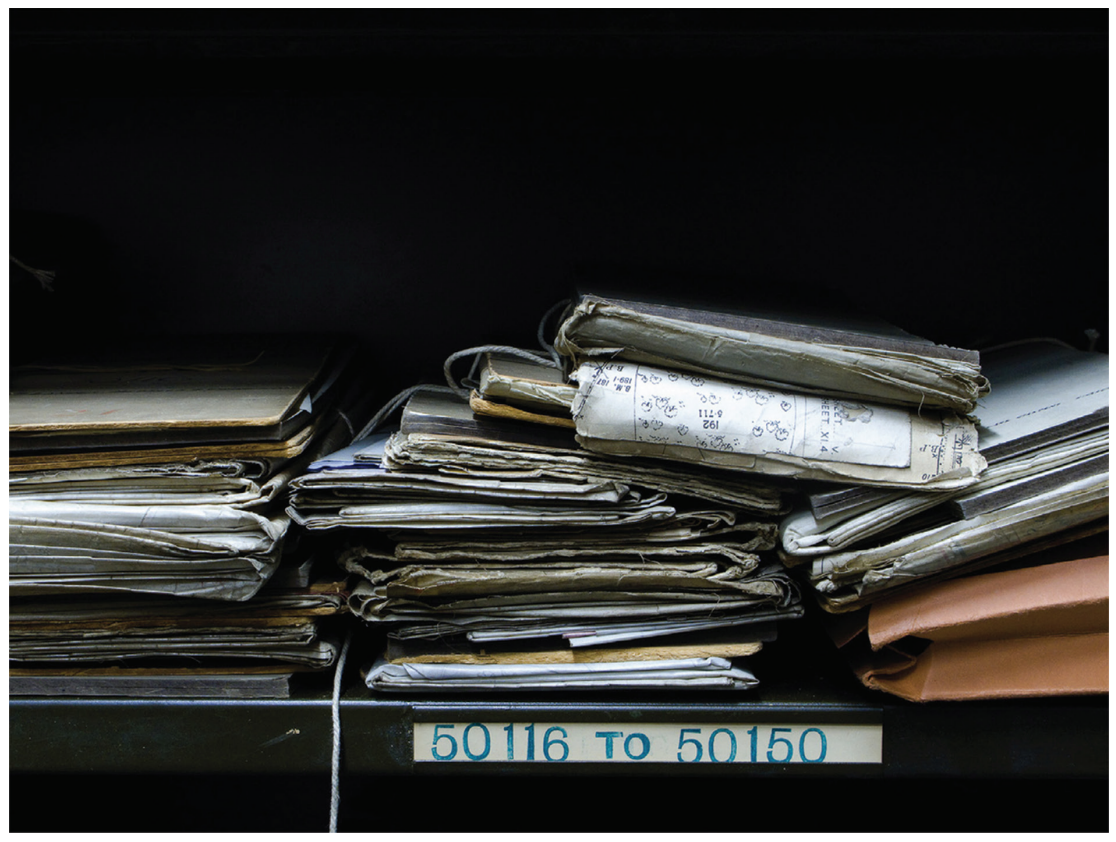

The contents of a Strong Room had remained untouched for almost forty years. I recorded this archive the day before it was to be removed to a modern storage facility. This paper-based archive included blueprints, planning documents and other filing relating to the work of borough architects and engineers. Aspects of individuals are expressed by handwriting, the use of different pens and pencils and the organisation of the space. When I later proposed to photograph this archive in its new location, I was told it had been water-damaged and my request was declined.

The Maintenance Room had been used by the same handy man for over thirty years. When he died the space remained as he had left it. I photographed the contents of small metallic drawers, which contained nuts and bolts, impeccably archived in disused tobacco tins and other old packaging.

Jane and I met a number of times, using prints of the photographs as a starting point for discussions and to develop ideas for the book, its approach and content growing organically. The physical world and the connections we make with it are important to both of us in our work, 


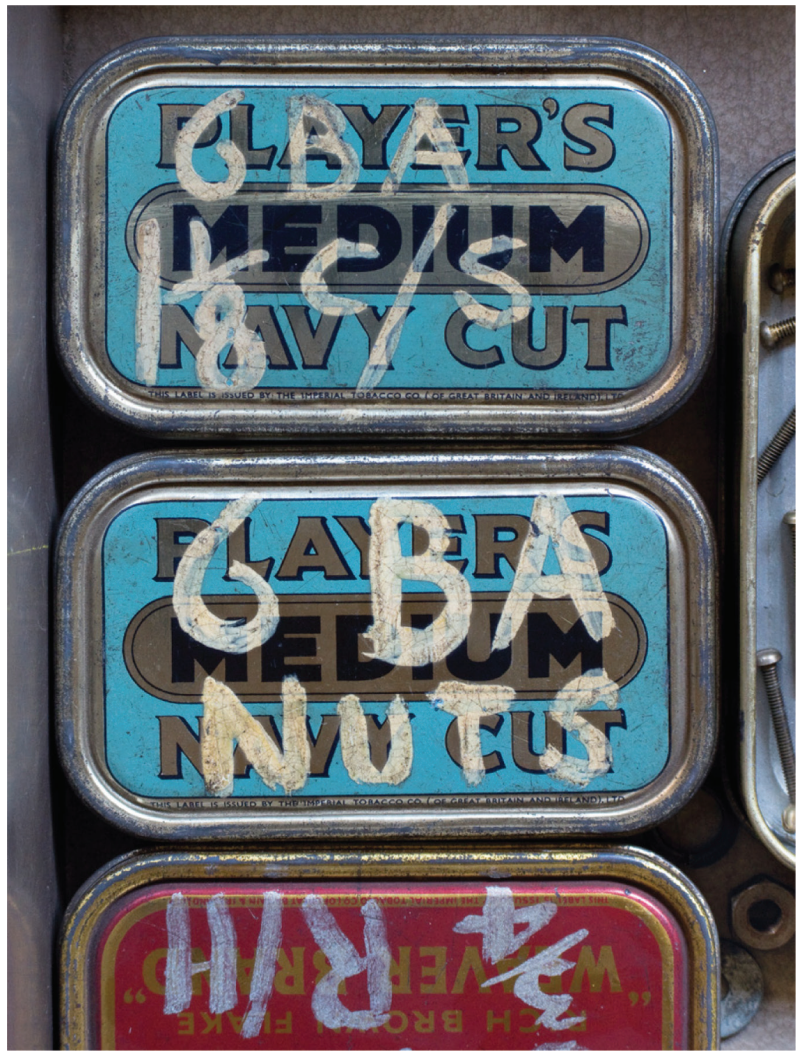

and we were concerned about the impact of the lack of tactile human experience in the digital world. Material qualities help bring ideas and memories to the surface: every scratch, every mark, every tear tells a story.

After picture selection, I wrote a brief introductory essay, "Strong Room" about my concerns about this physical lack, this basic human need. Jane then wrote her essay, "A Visit to the Archives," responding to her practice, in which she spends much time in museum archives, calling up documents, researching, reading and writing.

The three sets of photographs were taken digitally and the raw picture files had been stored away neatly in relevant folders-virtual archiveson a digital cloud server, where they had no purpose, no meaning, as no one apart from me, the photographer, had access to them.

By printing the images onto the pages of a book, the three archives have become part of the physical world, the book Strong Room becoming a paper-based archive itself. 
Writing about Strong Room in Source: The Photographic Review, Daniel Jewesbury describes the book as an example of a changing world that is moving from analogue/physical to digital/non-physical:

'Here are tiny individual deaths, of experience and knowledge and tactile memory, quotidian interactions between the mental and the physical, in the old "real" world, which, we now know, is merely a huge explanatory model of digital information, like those coloured balls connected with white sticks that are used to demonstrate atomic structures; a model where things with mass and dimensions in space represent data forms which, in truth, have neither. The book captures the passing into irrelevance, or historical curiosity, of the world-model'. ${ }^{16}$

Strong Room has now become part of a number of non-digital archives: from the book shelves of those who have purchased it, to the archives in one of the biggest Strong Rooms of the world, the British Library; as well as in other libraries including the MoMA Library in New York, USA, the Brooklyn Museum Library in New York, USA and the Chelsea College of Arts Library, London, UK.

\section{STRONG ROOM}

\section{Roelof Bakker}

In the digital world there is no need for paper, for pens and pencils, for handwritten notes, for printed documents, for files. There are no metal cupboards to store archives; there are no solid and secure strong rooms. There's nothing to touch, to feel, to smell, to flick through, to roll up, to organise in piles, to accidentally rip. There's no wear and tear, no material, no physical presence, no volume, no weight.

The huge uptake and appeal of apps is making many objects and products physically extinct too, and the human need for dynamic tactile interaction is denied. Thousands of tangible objects are replaced by virtual equivalents that exist solely on a flat screen and offer the user only the appearance of the real thing.

The "replacement" apps have no texture, no variety of finishes or materials, no difference in weight, scale, shape or design. They don't require any physical handling apart from users' thumbs scrolling and selecting options, a kind of "thumbing down".

You will never find a scratched and worn man-handled app in a second-hand shop.

We have password protection for computers, devices, email accounts, websites, servers. When our time is up, our information, our filed history, our communications, our photographs, our thoughts and ideas will be 
lost forever if no one knows the passwords, if no one has the keys, to our virtual strong rooms.

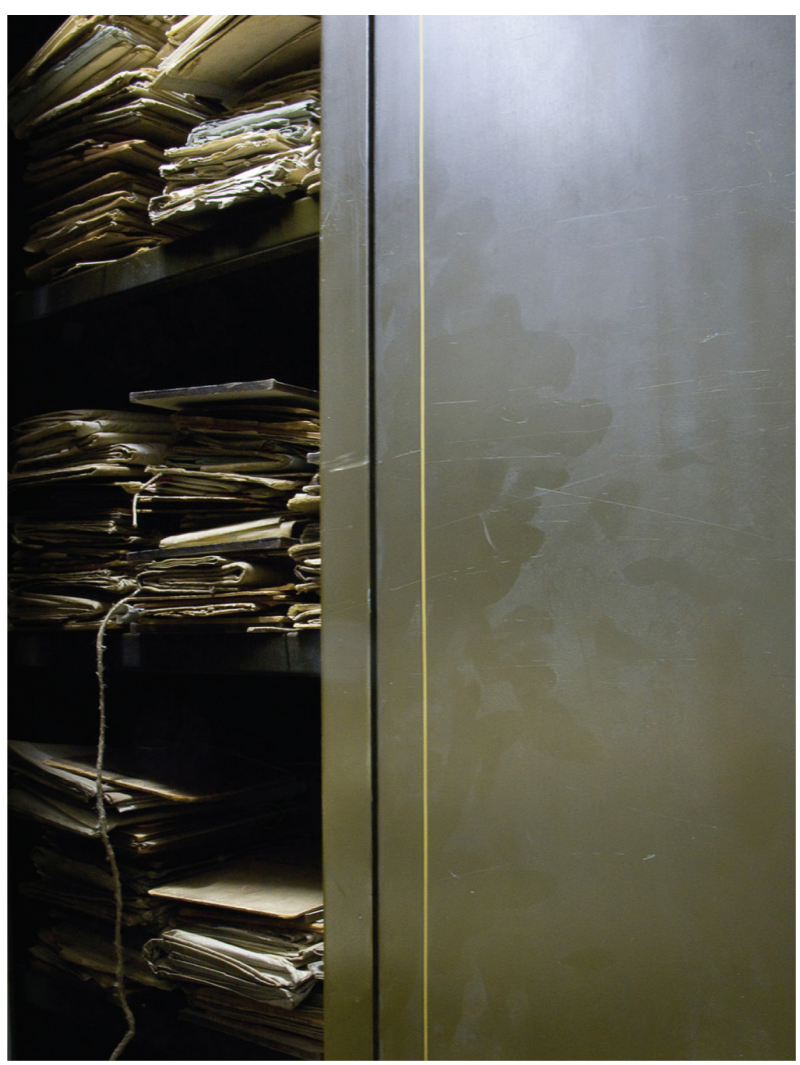

JW: When Roelof invited me to write an essay to accompany his photographs documenting traces of past human activity at Hornsey Town Hall, I was halfway through my doctoral research in the School of Art and Design History at Kingston University London. ${ }^{17}$ My practice-based doctoral project was framed as an artist's response to the UK Government's Guidance for the Care of Human Remains in Museums, ${ }^{18}$ which was published to accompany a change to the law in response to claims from Indigenous peoples for return of their ancestors' remains from museum collections. ${ }^{19}$ As part of my research, I was investigating the background to a statement in the Guidance that 'some human remains were acquired [for museums] between 100 and 200 years ago from Indigenous peoples in colonial circumstances where there was a very uneven divide of power' ${ }^{20}$ I was also 
exploring the 'unique status' the Guidance ascribes to human remains in museums: as objects used for research, teaching and display, which may also be perceived as subjects, with 'personal, cultural, symbolic, spiritual or religious significance to individuals and, or, groups'. ${ }^{21}$

Researching into the circumstances in which human remains were collected for museums during the late nineteenth century-a moment in the history of science described by Stephen J. Gould as 'the heyday of craniology'22 - I visited the library at the Royal College of Surgeons of England on an almost daily basis during the early autumn of 2013. Consulting the digital catalogue, I accessed a large archive of letters from suppliers in the colonies, who acquired human osteological material for the purposes of physical anthropological research during the 1860s to 1880 s. Working from the original letters, I transcribed hundreds of first-hand accounts of the removal of human skulls and bones from the recently dead in hospitals; from graves, both new and old; from execution grounds and battlefields. Many of the correspondents-who included medical, military and naval officers; clergymen and missionaries; diplomats, colonial officers, explorers and museum curators-revealed their knowledge of and disdain for local mourning customs: which they routinely disrupted, in order to keep up the supply of osteological specimens that provided data for comparative (and long since discredited) theories of the "races of mankind".

As a doctoral researcher, it was essential I presented my findings in an appropriately rigorous way. As an artist, I was anxious to be a credible witness. But I could not ignore the emotional response I was experiencing with regard to the evidence I was discovering. Delving into the correspondence-with its vivid glimpses into the lives of those who mined the deaths of peoples whose lands were occupied by force-the material qualities of the letters worked on my senses: resonating with distant, though nonetheless acute memories of the experience of death and mourning in my own life.

The opportunity to reflect on these reactions in a piece of creative writing, in response to Roelof's photographs and in the context of our conversations about his concern with the loss of tangible experience and lack of physical presence in the digital world, proved a timely gift for me. Liberated from the academic framework of my thesis, though still informed by the principle of examining and carefully assessing evidence, I had an opportunity to explore a range of thoughts and associations that preoccupied me during my visits to the archives at the Royal College of Surgeons. The result was a sliver of life writing, the content of which, though central to the development of my thesis, would otherwise have gone unrecorded. 


\section{A VISIT TO THE ARCHIVES (EXCERPT)}

\section{Jane Wildgoose}

In the farthest corner of the Library a door opens and the Archivist emerges from who knows what darker, labyrinthine and more densely book-lined nether region than this light and spacious room. She is delivering the volume I called up from the online catalogue on the small illuminated oblong of my laptop, from which I access seemingly limitless data, streaming on page after page, like some latter-day mantra: title, date, "extent", shelf number; title, date, "extent", shelf number...until I alight on this single item, a $19^{\text {th }}$ century album of correspondence with the Conservator of the Medical Museum adjoining the Library where I wait.

The Archivist approaches and I see that the streaming data, pixelated in never-varying silvery-blue light on my laptop, has miraculously transmigrated into a substantial handmade volume bound in the skin of some long dead animal, dyed a green as bright as the leaves outside-though now worn and scuffed, from years of being handled. Here, in the flesh, this item is treated with considerable care. The Archivist lays it cautiously in the waiting cradle and the binding creaks as the cover is gently laid open. She goes in search of grey foam wedges, then, standing back, head slightly to one side, judging a precise number of segments, gently inserts them one by one beneath the aged bulk, until it is supported just so. The Archivist withdraws to a desk near the entrance to the Library, and I am left to my own devices with this precious tome-though of course I know that I remain under constant observation from the desk, and surveillance from who knows what person, or persons unknown, unseen, on overhead CCTV.

But if I am conscious that I am being watched then I must also confess: I have come here myself, today, to eavesdrop. This weighty album contains letters from men long deceased-and I have come to listen in to them. And to peer: into their often barely decipherable accounts of the business of the dead. For these men, in their time, transported bones-in quite extraordinary numbers-from graves in Empire's remotest corners to this eminent institution, at the behest of a man who believed that specimens kept for research 'must be treated as books in a library, and be used only for consultation and reference by those who are able to read and appreciate their contents'. ${ }^{23}$ Inside the album, aged rectangles of papercreamy white resilient wove; flimsy, faded blue; lugubrious black-bordered mourning stationery — are pasted haphazardly onto dense browned pages that feel like blotting paper beneath my fingers.

As I gently turn the pages, a faint dry smell is released. It hangs in the air and I pause, instinctively. For a moment it is as though I am hovering, 
uncertainly, in more than one place at a time. Certainly I am here with this album in this elegant, classical Library. But also I am in a Sussex village thirty years ago: returning to collect my father's music books; visiting the familiar house, that had been rendered unfamiliar by the removal of his belongings in the weeks that followed his funeral. And I remember lifting a volume slowly up to my face, before placing it in a box; breathing in the old, comforting smell embedded in its pages, before wandering off through the house, now empty of everything except for a few last things: the music books, the piano and the bed. Downstairs, I opened the lid of the piano and ran my fingers lightly over the keyboard. Upstairs, I turned back the cover on the bed-and there were my father's clothes, set out neatly on the mattress. Pausing over the letters in front of me, I recall my vivid shock - the way it passed through me like a surge of electricity-as if the clothes had been his body, laid-out on the bed beneath my hand.

The clock ticks steadily on. The past has opened up with the album, stretching and yawning in the essence that will still cling to things. My younger woman's grief and its embodiment called up with this correspondence that resurrects the distant dead-bones displaced from dark earth, shipped across wide seas; skulls measured, numbered, defined and differentiated, set on shelf upon systematic shelf in metropolitan institutions. Ashes laid down in dark, strong rooms, delivered this day into autumn daylight.

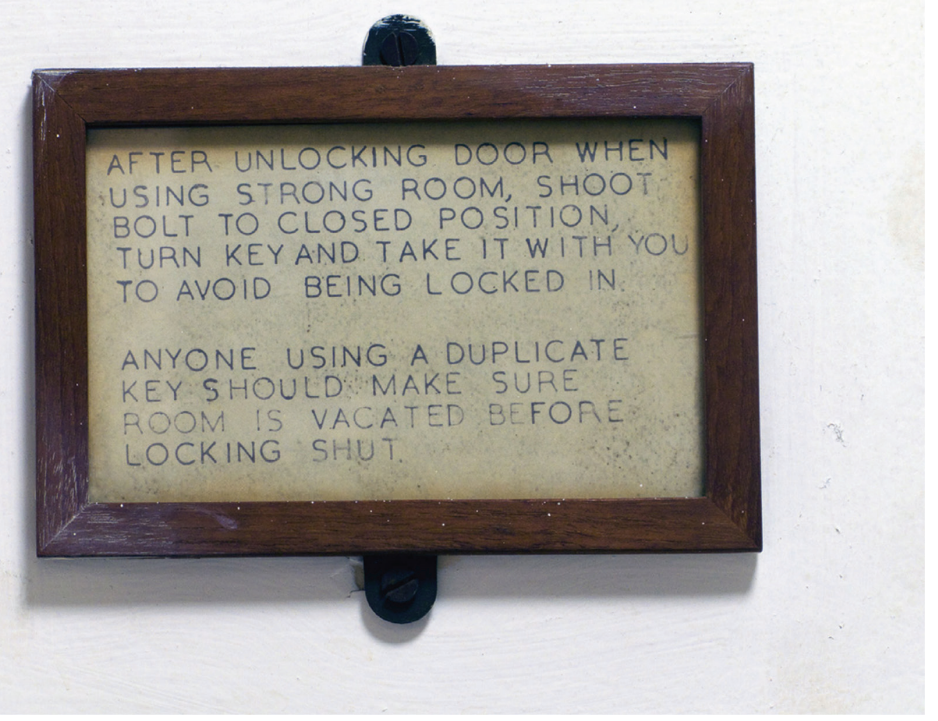


RB \& JW: We are now thinking about developing Strong Room Unlocked: a new publication with the original Strong Room at its heart. We aim to open up the themes we explored in Strong Room to new contributors and are planning to issue a call inviting writers to submit up to 3,000 words of fiction or non-fiction, in response to the themes of the loss of the tangible in the digital environment and/or the materiality of paper-based sources and archives. We want to extend our thinking about the speed with which text and image are moving from paper to screen-based media and the inability to leave physical traces in the digital world. In particular, we are interested in raising questions about how these changes may affect our writing, our sense of history, our interactions with one another and our perception of the significance of traces of "life-writing" that are left on the material world.

\section{WORKS CITED}

Bakker, Roelof and Jane Wildgoose. Strong Room. London: Negative Press, 2014.

Department for Culture, Media and Sport. Guidance for the Care of Human Remains in Museums. London: DCMS, 2005.

Duclos, Rebecca. "The Compulsive Browse: the role of research in contemporary Canadian art practices." Graphic Standards website. http://graphicstandards.org/the_compulsive_ browse.htm, accessed 03/10/2017.

Duclos, Rebecca. "Where inspiration meets investigation." Concordia University website. http://www.concordia.ca/now/what-we-do/research/20110214/where-inspiratiomeetsinvestigation.php, accessed 03/10/2017.

Flower, William Henry. Essays on Museums and Other Subjects Connected with Natural History. London: Macmillan \& Co., Ltd, 1898.

Gould, Stephen J. The Mismeasure of Man. New York \& London: Norton \& Company, 1996.

Howe, Susan. "Spontaneous Particulars: The Telepathy of Archives, Woodberry Poetry Room." Harvard University on YouTube, 16 October 2014. https://www.youtube.com/ watch?v=ZTGPbiUm-3o, accessed 04/10/2017.

Jewesbury, Daniel. "Self Published Books." Source: The Photographic Review 78 (Spring 2014): 77.

Mbembe, Achille. "The Power of the Archive and its Limits." Eds. C. Hamilton, V. Harris, J. Taylor, M. Pickover, G. Reid, R. Saleh. Refiguring the Archive. Dordrecht, Boston \& London: Kluwer Academic Publishers, 2002.

Russell, Lynette. A Little Bird Told Me: Family Secrets Necessary Lies. Crows Nest N. S. W.: Allen \& Unwin, 2002.

Russell, Lynette. "Indigenous Knowledge and Archives: Accessing Hidden History and Understandings." Australian Academic and Research Libraries 36.2 (2005): 161-171. DOI: 10.1080/00048623.2005.10721256.

Singh, Dayanita. File Room. Göttingen: Steidl, 2013.

Taylor, Jane. "Holdings: Refiguring the Archive." Eds. C. Hamilton, V. Harris, J. Taylor, M. Pickover, G. Reid, R. Saleh. Refiguring the Archive. Dordrecht, Boston \& London: Kluwer Academic Publishers, 2002.

Wildgoose, Jane. Collecting and Interpreting Human Skulls and Hair in Late Nineteenth Century London: "Passing Fables E' Comparative Readings at The Wildgoose Memorial Library"; An artist's response to the DCMS "Guidance for the Care of Human Remains in Museums" (2005). [Unpublished] PhD thesis, Kingston University London, 2015.

UK Human Tissue Act 2004, Section 47. 


\section{ABOUT THE AUTHORS}

Roelof Bakker is a photographer and publisher of Negative Press London. His work addresses the ever-increasing speed and momentum of contemporary life and the often tragic disposability of memory and the material. Negative Press publications include How Many Hopes Lie Buried Here Mother (2016), Strong Room (2014) with artist/writer Jane Wildgoose and Still (2012): a collaboration with twenty-six writers, runner-up Best Mixed Anthology at the 2013 Saboteur Awards. He is currently studying for a Masters in Photography at Cambridge School of Art/Anglia Ruskin University, Cambridge, UK.

Jane Wildgoose was awarded her Ph.D. at Kingston University London in 2015. She is an artist and researcher and Visiting Senior Research Fellow in the Centre for Life-Writing Research at King's College London. Her practice centres on collecting, memory and remembrance. She works to commission with museums and has exhibited at Waddesdon Manor (Rothschild Collections/National Trust) and Sir John Soane's Museum in the UK and Yale Center for British Art in the USA. Recent publications include "Ways of Making with Human Hair and Knowing How to 'Listen' to the Dead" (West 86 $\left.{ }^{\text {th }}, 23.1,2016\right)$; "Collecting Human Skulls and Hair: In Pursuit of Wonder in Death's Chambers," in Wonder in Contemporary Artistic Practice, Christian Mieves and Irene Brown, ed. (Routledge, 2017).

\section{NOTES}

1 Duclos, Rebecca, "The Compulsive Browse: the role of research in contemporary Canadian art practices." Graphic Standards website. http://graphicstandards.org/the_compulsive_ browse.htm accessed 03/10/2017.

2 Duclos, Rebecca, quoted in Herland, Karen, "Where inspiration meets investigation." Concordia University website. http://www.concordia.ca/cunews/main/stories/2011/02/14/whereinspiration-meets-investigation.html accessed 03/10/2017.

3 Duclos, Rebecca, "The Compulsive Browse."

4 Howe, Susan, "Spontaneous Particulars: The Telepathy of Archives, Woodberry Poetry Room.” Harvard University on YouTube, 16 October 2014. https://www.youtube.com/ watch?v=ZTGPbiUm-3o accessed 04/10/2017.

5 Singh, Dayanita, File Room. Göttingen: Steidl, 2013 (no pagination).

6 Mbembe, Achille, "The Power of the Archive and its Limits." In: Hamilton et al. (ed.), Refiguring the Archive. Dordrecht, Boston \& London: Kluwer Academic Publishers, 2002 (p. 20).

7 See: Taylor, Jane, "Holdings: Refiguring the Archive." In: Hamilton et al., 2002 (pp. 243-282).

8 Mbembe, Achille 2002 (pp. 19-20).

9 Taylor, Jane 2002 (p. 243).

10 Mbembe, Achille 2002 (p. 22, p. 25).

11 Russell, Lynette, "Indigenous Knowledge and Archives: Accessing Hidden History and Understandings." Australian Academic and Research Libraries 36.2, 2005, 163-165. DOI 10.1080/00048623.2005.10721256. Also see: Russell, Lynette, A Little Bird Told Me: Family Secrets Necessary Lies. Crows Nest, N. S. W.: Allen \& Unwin, 2002.

12 Mbembe, Achille 2002 (p. 25).

13 Russell, Lynette 2005 (p. 163). 
14 Idem, (p. 170).

15 Wildgoose, Jane, The Wildgoose Memorial Library presents. Hornsey Town Hall, 2008; Bakker, Roelof, Still. Hornsey Town Hall, 2010.

16 Jewesbury, Daniel, "Self Published Books." Source: The Photographic Review 78, Spring 2014, 77.

17 Wildgoose, Jane, Collecting and Interpreting Human Skulls and Hair in Late Nineteenth Century London: "Passing Fables \& Comparative Readings at The Wildgoose Memorial Library"; An artist's response to the DCMS "Guidance for the Care of Human Remains in Museums" (2005). [Unpublished] PhD thesis Kingston University London, 2015.

18 Department for Culture, Media and Sport, "Guidance for the Care of Human Remains in Museums." London: DCMS, 2005. "Guidance for the Care of Human Remains in Museums," National Archives website, archived on 12 May 2010, http://webarchive.nationalarchives. gov.uk/+/http://www.culture.gov.uk/reference_library/publications/3720.aspx accessed 25/07/2017.

19 "Human Tissue Act 2004," "47 Power to de-accession human remains." legislation.gov.uk website. http://www.legislation.gov.uk/ukpga/2004/30/section/47 accessed 25/07/2017.

20 Department for Culture, Media and Sport, 2005 (p. 8).

21 Idem, (p. 7).

22 Gould, Stephen J., The Mismeasure of Man. New York \& London: Norton \& Company, 1996 (p. 105).

23 Flower, William Henry, Essays on Museums and Other Subjects connected with Natural History. London: Macmillan \& Co., Ltd, 1898 (p. 15). 